\title{
Effects of Margarine Containing Medium-Chain Triglycerides on Diet-Induced Thermogenesis
}

\author{
Yoshie SUZUKI $^{1}$, Naohisa Nosaka ${ }^{1}$, Hideaki MAKI ${ }^{1}$, Michio KASAI $^{1 *}$, Toshiaki Aoyama ${ }^{1}$, \\ Hirofumi Haruna ${ }^{2}$, Tooru Toda ${ }^{2}$, Mitsuko OKaZaKi ${ }^{3}$, Osamu Igarashi ${ }^{4}$ and Kazuo Kondo ${ }^{\mathbf{5}}$ \\ ${ }^{1}$ Division of Healthcare Science Research Laboratory, The Nisshin Oillio Group, LTD. \\ (1 Shinmei-cho, Yokosuka, Kanagawa, 239-0832, JAPAN) \\ ${ }^{2}$ Food Research and Development Center, The Nisshin Oillio Group, LTD. \\ (1 Shinmei-cho, Yokosuka, Kanagawa, 239-0832, JAPAN) \\ ${ }^{3}$ Kagawa Nutrition University \\ (3-9-21 Chiyoda, Sakado, Saitama 350-0288, JAPAN) \\ ${ }^{4}$ Ibaraki Christian University \\ (6-11-1 Oomika-cho, Hitachi, Ibaraki, 319-1295, JAPAN) \\ ${ }^{5}$ Institute of Environmental Science for Human Life, Ochanomizu University \\ (2-1-1 Ohtsuka, Bunkyo-ku, Tokyo 112-8610, JAPAN)
}

Edited by K. Miyashita, Hokkaido Univ., and accepted January 20, 2005 (received for review November 30, 2004)

\begin{abstract}
This study investigates the effects of margarine containing medium-chain triglycerides (MCT-M) on diet-induced thermogenesis(DIT) and was conducted in double-blind, cross-over design. Twenty-five healthy subjects in the first part of the study (study1) and 7 healthy women in the second (study2) participated in this examination. Long-chain triglycerides (LCT) were prepared with a blend of rapeseed oil and soybean oil (LCT-M). Sandwiches with MCT-M or LCT-M and clear soup were used as test food in the first part and in the second pound cake and ice cream containing MCT-M or LCT-M. Oxygen consumption and carbon dioxide production were measured by indirect calorimetry. Resting energy expenditure was determined based on there parameters, applying the equation of Weir. Increase in oxygen consumption after eating MCT-M sandwiches at 60 and 120min was found significantly greater than for LCT-M sandwiches, as was also noted after eating MCT-M pound cake and MCT-M ice cream at $60 \mathrm{~min}$. DIT after eating sandwiches with MCT-M during 6h was clearly more than noted for LCT-M, and after pound cake and ice cream consumption with MCT-M during 4h significantly exceeded that for LCT-M. The intake of MCT-M would thus appear to lead to greater DIT, compared to that following LCT-M consumption, irrespective of the made of food preparation.
\end{abstract}

Key words: medium-chain triglyceride, diet-induced thermogenesis, margarine, pound cake, ice cream, human

\footnotetext{
Abbreviations: DIT, diet-induced thermogenesis; MCFA, medium-chain fatty acids; MCT, medium-chain triglycerides; LCFA, long-chain fatty acids; LCT, long-chain triglycerides; RQ, respiratory quotient; REE, resting energy expenditure
}

\begin{abstract}
1 緒言
肥満は脂肪が過剩蓄積した状態であり，撕取エネル ギーが消費エネルギーを上回ることにより発症する。 更に肥満は, 高脂血症, 高血圧, 動脈硬化, 糖尿病な
\end{abstract}

${ }^{*}$ Correspondence to: Michio KASAI, Division of Healthcare Science Research Laboratory, Nisshin Oillio Group, LTD., 1 Shinmei-cho, Yokosuka, Kanagawa, 239-0832, JAPAN

E-mail:m-kasai@nisshin-oillio.com 
ど生活習慣病の主要な危険因子であることが知られて いる。食事誘発性体熱産生（DIT）は 1 日のエネルギー 消費量の $10 \%$ 前後を占めており，エネルギー消費量を 算出する上で重要な要因である。このエネルギーの出 納バランスにより大半が脂肪の蓄積及び抑制に関わっ ている。DIT に影響を及ぼす食品素材としてカプサイ シンやカフェイン, 脂肪酸などの研究が進められてい る $(1-3)$ 。脂肪酸の中でも, 通常摂取している食用油 脂は炭素数が 12 以上の長鎖脂肪酸（LCFA）で構成さ れている。また，最近魚油の LCFA でDIT に影響を及 ぼす事が報告されている（4）。一方，中鎖脂肪酸 （MCFA）はエネルギー消費量を増加することが多くの 研究者により報告されている（5-7）。MCFA は炭素数 8 から 10 の脂肪酸で, 主に天然のパーム核油やヤシ油, 牛乳に含まれている。国民栄養調査を基に日本人の MCFA 㠌取量を推定すると，1 日あたり $0.2 \sim 0.3 \mathrm{~g}$ 程度 と考えられている (8)。近年の研究で MCFAの摂取 は, ヒトの体脂肪の蓄積を抑制することが明らかと なっている (9)。その中でNosaka ら（10）は $5 \mathrm{~g}$ とい う少量の中鎖脂肪酸トリグリセリド（MCT; MCFA 結 合油脂）の撕取で体脂肪の蓄積抑制を確認している。 そのメカニズムの一つとして, エネルギー消費の増加 をあげているが, DIT 充進に関する研究に扎いて MCT $10 \mathrm{~g}$ 以下での報告例はほとんどない。そこで本研究は 5 $\mathrm{g}$ の MCT を含むファットスプレッドの DIT 元進効果に ついて検討し, 更に MCT を幅広い加工油脂食品に応用 するため, 加熱や凍結などの調理操作を行なった食品 について MCT の DIT 六進効果に影響を及ぼすかどう かについて合わせて検討を行った。

\section{2 試験方法}

\section{$2 \cdot 1$ 被験者}

試験 1 は健常成人 25 名（男性 11 名, 女性 14 名：平 均年齢 $28.9 \pm 1.05$ 歳, 身長 $165.6 \pm 1.43 \mathrm{~cm}$, 体重 60.1 $\pm 2.14 \mathrm{~kg}$, BMI $\left.21.8 \pm 0.52 \mathrm{~kg} / \mathrm{m}^{2}\right)$ を対象とした。試 験 2 は健常成人女性 7 名（平均年齢 $30.4 \pm 1.91$ 歳, 身 長 $161.2 \pm 1.13 \mathrm{~cm}$, 体重 $53.0 \pm 2.52 \mathrm{~kg}$, BMI $20.4 \pm$ $\left.0.89 \mathrm{~kg} / \mathrm{m}^{2}\right)$ を対象とした。また, 本試験はお茶の水女 子大学倫理委員会の承認を得て, ヘルシンキ宣言 （1964 年制定，2000 年修正）の精神に則り実施した。 全ての被験者には事前に試験の主旨や方法について充 分な説明を行い, 同意を得た後, 試験を実施した。

\section{$2 \cdot 2$ 試験食}

試験 1） $5 \mathrm{~g}$ の MCT を含有するファットスプレッド $(14 \mathrm{~g})$ とジャム $(30 \mathrm{~g})$ を食パン $(120 \mathrm{~g})$ にはさんだ サンドイッチ (MCT 食) と, 市販のインスタントコン
ソメスープ（160 ml）を用いた。

試験 2） $5 \mathrm{~g}$ の MCT を含有するファットスプレッド を含むパウンドケーキ（52 g) 及びアイスクリーム (100 g) を用いた。パウンドケーキは MCT 含有ファッ トスプレッド $(100 \mathrm{~g})$ に上白糖 $(100 \mathrm{~g})$ ，全卵(85 $\mathrm{g})$, 薄力粉 $(100 \mathrm{~g})$, ベーキングパウダー（1 g) を加

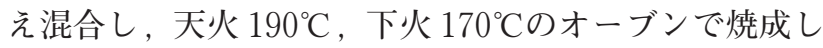
た。アイスクリームは, 水 $(60 \mathrm{~g})$ に水飴 $(5 \mathrm{~g})$, グラ ニュー糖 $(10 \mathrm{~g})$, 脱脂粉乳 $(10 \mathrm{~g})$ を加え混合後, MCT 含有ファットスプレッド（14.3 g) を添加し，ア イスクリーマーにかけ調製した。

試験食のサンドイッチ, コンソメスープ, パウンド ケーキは常温で，アイスクリームは摂取 1 時間前に保 冷箱に移し, 約一 $7^{\circ} \mathrm{C}$ の状態で提供した。両試験とも対 照食（長鎖脂肪酸トリグリセリド食； LCT 食）には MCT 考一般的に家庭で使用されている調合油（菜種： 大豆； 7:3(w/w)）に置換えたファットスプレッドを 用いた (Table 1, 2)。

\section{$2 \cdot 3$ 試験方法}

本試験は二重盲検交差法で行った。試験期間中, 被 験者は普段の生活サイクル及び食生活を保たせた。試 験日前日は21：00 以降の飲食は水のみとした。試験日 は測定室に $9 ： 00$ に集合し, 身長及び体重を測定後, 呼気ガス測定まで椅子に座りリラックス状態を保った。 10：00より損取前の呼気ガスを測定した。MCT 食もし くは LCT 食の撕取後 30 分及び 1 時間を測定し，それ 以降は 1 時間間隔で 6 時間まで呼気ガスを測定した。 なお, 試験 2 は試験食のカロリーが低いことから全員 の安静時代謝量（REE）が㠌取前の状態に戻った摂取 後 4 時間で測定を終了した。呼気ガス中の酸素消費量 及び二酸化炭素排泄量の測定はエアロモニターAE-300 $\mathrm{S}$ (ミナト医科学(株), 大阪) を用いた。非タンパク呼 吸商 $(\mathrm{RQ})$ は酸素消費量及び二酸化炭素排泄量より算 出した。REE は Weir の式を使い, 酸素消費量及び二酸 化炭素排泄量より求めた（11）。エアロモニター AE300Sのガス分析法は酸素分析にダンベル型酸素濃度計 を, 二酸化炭素分析に赤外線吸収式炭酸ガス濃度計を 用いて行った。椇食試験実施後, 3 日以上の間隔を開け て, 異なる油脂について試験を行った。なお，女性の 被験者については月経周期により熱産生量が異なるた め, 試験日を高温期もしくは低温期の同一周期になる ように日程調整を行った。測定室の気温は $25-26^{\circ} \mathrm{C}$, 湿度は50ー55\%に設定した $(12-14)$ 。

\section{$2 \cdot 4$ 統計解析}

全ての值は平均值士標準誤差で示した。MCT 食もし くは LCT 食摂取後の酸素消費量及び RQ は繰り返しの 
Table 1 Fatty Acid Composition of Test Margarines.

\begin{tabular}{ccc}
\hline Fatty acid & $\begin{array}{c}\text { Long-chain } \\
\text { triglycerides }\end{array}$ & $\begin{array}{c}\text { Medium-chain } \\
\text { triglycerides }\end{array}$ \\
\hline $8: 0^{2}$ & $\mathrm{~g} / 100 \mathrm{~g}$ total fatty acids \\
$10: 0$ & $\mathrm{ND}^{3}$ & 39.0 \\
$12: 0$ & $\mathrm{ND}$ & 13.0 \\
$14: 0$ & 0.1 & 0.1 \\
$16: 0$ & 0.4 & 0.4 \\
$16: 1$ & 19.3 & 16.3 \\
$17: 0$ & 0.1 & 0.1 \\
$18: 0$ & 0.1 & $\mathrm{ND}$ \\
$18: 1$ & 4.7 & 3.6 \\
$18: 2$ & 47.9 & 22.3 \\
$18: 3$ & 19.7 & 3.3 \\
$20: 0$ & 5.9 & 0.9 \\
$20: 1$ & 0.5 & 0.3 \\
$22: 0$ & 0.7 & 0.2 \\
$22: 1$ & 0.3 & 0.1 \\
$24: 0$ & 0.1 & $\mathrm{ND}$ \\
$24: 1$ & 0.1 & 0.1 \\
Others & 0.1 & $\mathrm{ND}$ \\
Total & 0.0 & 0.3 \\
\hline
\end{tabular}

${ }^{1}$ Blended mixture of rapeseed and soybean oils (7:3)

${ }^{2}$ Number of carbon atoms: number of double bonds.

${ }^{3} \mathrm{ND}$, not detected.

Table 2 Nutrient and Energy Contents of Test Meal.

\begin{tabular}{lccc}
\hline & Sandwich & Pound cake & Ice cream \\
\hline Energy (kcal) LCT MCT & 499495 & 215210 & 183178 \\
Protein (g) & 11.7 & 2.6 & 3.4 \\
Fat (g) & 15.5 & 11.3 & 10.0 \\
Carbohydrate (g) & 77.4 & 24.7 & 19.7 \\
\hline
\end{tabular}

Test meals of energy, protein, fat, and carbohydrate were calculated by the dietitian on the basis of the Fifth revision of the Standard Table of Food Composition in Japan. (2000)

二元配置分散分析（油脂 $\times$ 時間）を行い，有意差が確 認されたものは，各時間ごとに対応のある $\mathrm{t}$ 検定を行 なった。DITの計算は台形法を用いた。 MCT 食及び LCT 食摂取後の DIT は一元配置分散分析を行い，有意 差が確認された場合，対応のある $\mathrm{t}$ 検定で解析した。 いずれも危険率 $5 \%$ 未満 $(P<0.05)$ で統計的有意差が あるとした。統計計算は SPSS Version 10.0J を使用し た。

\section{3 結果}

試験 1）被験者 25 名の試験食摂取前 REE，酸素消費 量及び RQ はそれぞれ，MCT 食群で $1479.9 \pm 43.7 \mathrm{kcal}$, $215.6 \pm 6.33 \mathrm{ml} / \mathrm{min}, 0.79 \pm 0.01$ 。LCT 食群で $1516.0 \pm$ $48.9 \mathrm{kcal}, 220.0 \pm 6.77 \mathrm{ml} / \mathrm{min}, 0.80 \pm 0.02$ であった。

MCT 食打よび LCT 食摂取後の酸素消費変化量は, すべての時間に扔いて MCT 食群が LCT 食群よりも高 值を示した。特に，撕取後 60 分，120 分ではそれぞれ MCT 食群が $33.20 \pm 2.80 \mathrm{ml} / \mathrm{min}, 27.84 \pm 2.70 \mathrm{ml} / \mathrm{min}$ 。 LCT 食群が $25.36 \pm 2.62 \mathrm{ml} / \mathrm{min}, 19.12 \pm 2.76 \mathrm{ml} / \mathrm{min}$ と，MCT 食群が有意な高值を示した（Fig. 1)。また， 撕取後 30 分の RQ に打いて MCT 食群で 0.79 , LCT 食 群で 0.81 と MCT 食群が有意に低值を示した（Fig. 2)。 試験食撕取後 6 時間の DIT は MCT 食群が LCT 食群に 比べ約 $7 \mathrm{kcal}$ エネルギー消費が増大しており，摂取した エネルギーに対し 1.6\%元進していた（Table 3)。

試験 2) 被験者 7 名のパウンドケーキ㠌取前の REE, 酸素消費量及び RQ は，それぞれ MCT 食群で $1328.0 \pm$ $64.7 \mathrm{kcal}, 193.3 \pm 9.54 \mathrm{ml} / \mathrm{min}, 0.78 \pm 0.02$ 。LCT 食群 で $1365.1 \pm 62.9 \mathrm{kcal}, 199.9 \pm 9.78 \mathrm{ml} / \mathrm{min}, 0.76 \pm 0.02$ であった。アイスクリーム摂取前の REE，酸素消費量 及び RQ は，それぞれ MCT 食群で $1282.1 \pm 75.7 \mathrm{kcal}$, $186.4 \pm 10.94 \mathrm{ml} / \mathrm{min}, 0.79 \pm 0.02$ 。LCT 食群で 1311.0 $\pm 69.2 \mathrm{kcal}, 192.0 \pm 10.44 \mathrm{ml} / \mathrm{min}, 0.77 \pm 0.01$ であっ た。MCT 食打よび LCT 食摂取後の酸素消費変化量は パウンドケーキで掑取後 60 分, 240 分，アイスクリー 厶は撕取後 60 分において MCT 食群が有意に高值を示 した（Fig. 3，4）。また， RQについてはアイスクリー 厶摂取後 30 分, 120 分に有意に低值を示した。試験食 掑取後 4 時間の DIT はパウンドケーキ，アイスクリー ムとも MCT 食群が LCT 食群に比べ有意にエネルギー 消費が増大し，エネルギー摂取量に対するDIT の割合 はパウンドケーキ及びアイスクリームでほぼ同程度の 増加が認められた（Table 4)。

\section{4 考察}

MCT の体脂肪蓄積抑制効果は 1950 年代から研究が 進められてきた。近年, 我々の研究グループはヒトを 対象として, MCT に体脂肪の蓄積抑制効果のあること を示した $(9,10)$ 。本研究ではその要因の 1 つと考えら れるDITの元進について, 少量（5 g) の MCT 撕取に おいても効果を示すかどうか検討した。試験結果から MCT $5 \mathrm{~g}$ 含有するファットスプレッドの撕取は LCT を同量含有するファットスプレッドの摂取に比べ，エ ネルギー産生の立進することが明らかとなった。 Seaton ら（3）は，健常男性 7 名に MCT $48 \mathrm{~g}$ または 


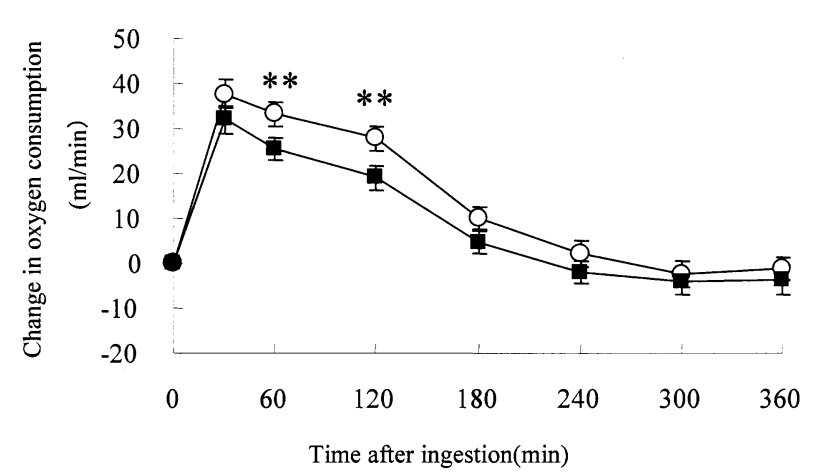

Fig. 1 Change in Oxygen Consumption before and after the Ingestion of Meal with Margarine Containing 5g of Long-Chain Triglycerides or Medium-Chain Triglycerides ${ }^{1,2}$.

${ }^{1}$ Mean $\pm \mathrm{SE} ; n=25$. $\bigcirc$; medium-chain triglycerides, $\mathbf{\square}$; long-chain triglycerides.

${ }^{2 * *}$ Significantly different from the meal containing $5 \mathrm{~g}$ LCT, $P<0.01$.

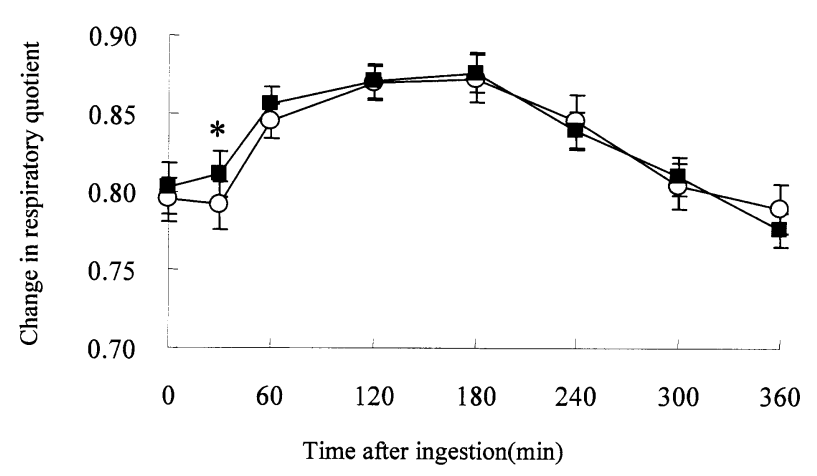

Fig. 2 Change in Respiratory Quotients before and after the Ingestion of Meal with Margarine Containing $5 \mathrm{~g}$ of Long-Chain Triglycerides or Medium-Chain Triglycerides ${ }^{1,2}$.

${ }^{1}$ Mean \pm SE; $n=25$. $\bigcirc$; medium-chain triglycerides, $\mathbf{\square}$; long-chain triglycerides. ${ }^{2 *}$ Significantly different from the meal containing $5 \mathrm{~g}$ LCT, $P<0.05$.

Table 3 Diet-induced Thermogenesis during $6 \mathrm{~h}$ after Ingestion of Meal with Margarine Containing $5 \mathrm{~g}$ of Long-Chain Triglycerides or Medium-Chain Triglycerides.

\begin{tabular}{lcr}
\hline & $\begin{array}{c}\text { Long-chain } \\
\text { triglycerides }\end{array}$ & $\begin{array}{c}\text { Medium-chain } \\
\text { triglycerides }\end{array}$ \\
\hline Diet-induced thermogenesis $(\mathrm{kcal})$ & $22.97 \pm 2.21^{1}$ & $30.45 \pm 3.04^{*}$ \\
Rate of diet-induced thermogenesis $(\%)^{2}$ & $4.60 \pm 0.44$ & $6.15 \pm 0.61^{*}$ \\
\hline${ }^{1}$ Mean \pm SE & \\
${ }^{2}$ Rate of diet-induced thermogenesis was calculated as diet-induced thermogenesis / \\
energy of food consumption \\
Significantly different from the meal containing $5 \mathrm{~g} \mathrm{LCT}, * P<0.01$.
\end{tabular}

コーン油 $45 \mathrm{~g}$ を含む飲料を与えたとき，コーン油では 摂取後の酸素消費量が摂取前に比べ約 4\%の増加に過ぎ なかったが，MCTでは約 12\%増加したことを報告して いる。同様に, Dulloo ら（5）は, メタボリックチャン バーを用いて $5 \mathrm{~g}$ の MCT を含む試験食を朝食, 昼食, 夕食にそれぞれ与え 24 時間安静時代謝を測定した。そ の結果から, MCT は LCTよりもエネルギー消費が立 進することを確認している。彼らの結果は本試験の結 果と良く対応している。更に, Dulloo らは24 時間の間 に排泄した尿中のノルアドレナリン分泌量を測定し， MCT が LCT よりも有意に促進することを確認した。 これは MCT が交感神経系を活性化させ，エネルギー消 費を増大させることを示唆している。このことから本 試験についても $5 \mathrm{~g}$ の MCT を攖取することにより交感 神経系が活性化され，体熱産生に影響したことが考え られる。また, 試験 1 の RQ は撕取後 30 分において
MCT 食群で LCT 食群よりも有意に低下している。こ のことは MCT が撕取後速やかに代謝され, 脂肪の酸化 が立進していることを示唆する。Scalfi ら（6）は肥満 者打よび肥満でない男性各 6 名に, $30 \mathrm{~g}$ の MCT を含む $1300 \mathrm{kcal}$ の食事を䀧取させたところ，エネルギー消費 量については両群とも MCT の摂取で増加したが， RQ の低下は, 肥満でない健常群でのみ認められた。われ わ机の研究でも試験 1 の被験者（BMI $21.8 \pm 0.52$ $\left.\mathrm{kg} / \mathrm{m}^{2}\right)$ で $\mathrm{RQ}$ の低下が認められており, 標準体重であ るほど脂肪酸化が充進しやすいのではないかと推察さ れる。

本研究のもう一つの目的は MCT 含有ファットスプ レッドに加熱や凍結などの調理操作を行なった場合, どのような影響があるかを検討することである。試験 食に用いたパウンドケーキは $190^{\circ} \mathrm{C} の$ 高温下で焼成, ア イスクリームは氷点下で涷結操作を行なった。2つの試 


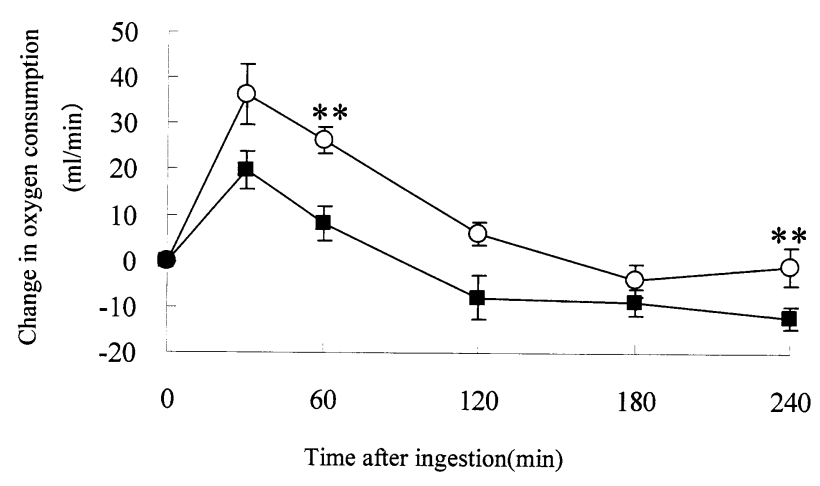

Fig. 3 Change in Oxygen Consumption before and after the Ingestion of Meal with Pound Cake Containing $5 \mathrm{~g}$ of Long-Chain Triglycerides or Medium-Chain Triglycerides ${ }^{1,2}$.

${ }^{1}$ Mean \pm SE; $n=7$. $\bigcirc$; medium-chain triglycerides, $\mathbf{\square}$; long-chain triglycerides.

${ }^{2} * *$ Significantly different from the meal containing $5 \mathrm{~g}$ LCT, $P<0.01$.

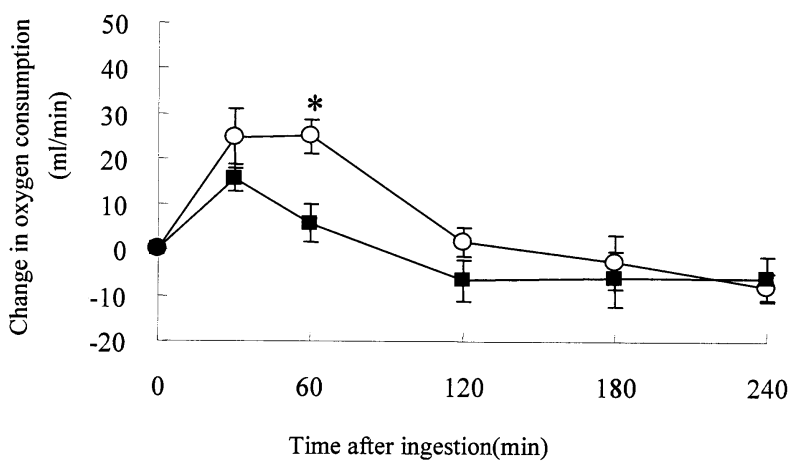

Fig. 4 Change in Oxygen Consumption before and after the Ingestion of Meal with Ice Cream Containing $5 \mathrm{~g}$ of Long-Chain Triglycerides or Medium-Chain Triglycerides ${ }^{1,2}$.

${ }^{1}$ Mean $\pm \mathrm{SE} ; n=7$. $\bigcirc$; medium-chain triglycerides, $\mathbf{\square}$; long-chain triglycerides. ${ }^{2} *$ Significantly different from the meal containing $5 \mathrm{~g} \mathrm{LCT}, P<0.05$.

Table 4 Diet-induced Thermogenesis during $4 \mathrm{~h}$ after Ingestion of Meal with Margarine Containing $5 \mathrm{~g}$ of Long-chain Triglycerides or Medium-chain Triglycerides.

\begin{tabular}{lccccc}
\hline & \multicolumn{2}{c}{ Pound cake } & & \multicolumn{2}{c}{ Ice cream } \\
\cline { 2 - 3 } \cline { 5 - 6 } Test oil & LCT & MCT & & LCT & MCT \\
\hline Diet-induced thermogenesis (kcal) & $5.43 \pm 1.10$ & $13.14 \pm 1.48^{* *}$ & & $6.38 \pm 1.61$ & $11.78 \pm 1.50^{*}$ \\
Rate of diet-induced thermogenesis $(\%)^{2}$ & $2.52 \pm 0.50$ & $6.26 \pm 0.70^{* *}$ & & $3.49 \pm 0.90$ & $6.62 \pm 0.80^{*}$ \\
\hline${ }^{1}$ Mean \pm SE & & &
\end{tabular}

験食の加熱温度には $200^{\circ} \mathrm{C}$ 以上の差があり，まったく異 なった調理操作を行っているが, MCT 食撕取後 4 時間 での掑取エネルギーに対するエネルギー消費量はパウ ンドケーキ，アイスクリームとも有意差なく同程度の 值を示した。このことから，MCFA は高温加熱や低温 凍結で分解や変性をすることはなく調理操作前と同等 の DIT 元進効果を維持していることが明らかになった。

ファットスプレッドはバターに比べ低温でも良展延 性を有し，カロリーも低いことから広く家庭に受け入 れられている。 MCT は融点がー $10^{\circ} \mathrm{C}$ と低く, 風味も一 般食用油と比較するとさっぱりしていることから， MCT を含有するファットスプレッドは LCT を含有す るファットスプレッドよりもロ溶けの良いあっさりと した風味となる。

これまで，MCT は経腸栄養剤やエネルギー補給を目 的とした治療食など医療分野で利用されている。しか し，低温度発煙や揚げ調理時の起泡性など調理適性の
問題から調理用油としての利用は進んでいない（15）。 したがって， MCTをファットスプレッドに加工するこ とはクッキーやパン，クリームなどの材料としても利 用できることから継続揁取が可能となる有効な手段と 考えられる。

今回の研究に扎いて, MCT 含有ファットスプレッド はエネルギー産生を充進し, 体脂肪の低蓄積性に寄与 していることが示唆された。MCTが今後さらに多くの 油脂加工食品に応用範囲が広がり, 健康増進の視点か ら肥満予防食として利用されることを期待する。

\section{謝 辞}

本研究を行なうにあたり試験食の作成にご協力いた だいた日清オイリオグループ(株) 業務用技術部の皆さ まに深く感謝申し上げます。 


\section{References}

1. C.J.K. HENRY and B. EMERY, Effect of Spiced Food on Metabolic Rate, Hum. Nutr. Clin. Nutr., Vol. 40, 165-168 (1986).

2. P. KOOT and P. DEURENBERG, Comparison of Changes in Energy Expenditure and Body Temperatures After Caffeine Consumption, Ann. Nutr. Metab., Vol. 39, 135-142 (1995).

3. T.B. SEATON, S.L. WELLE, M.K. WARENKO and R.G. CAMPBELL, Thermic Effect of Medium-Chain and LongChain Triglycerides in Man, Am. J. Clin. Nutr., Vol. 44, 630-634 (1986).

4. H. OUDART, R. GROSCOLAS, C. CALGARI, M. NIBBELINK, C. LERAY, Y. LE. MAHO and A. MALAN, Brown Fat Thermogenesis in Rats Fed High-fat Diets Enriched with n-3 Polyunsaturated Fatty Acids, Int. J. Obes. Relat. Metab. Disord., Vol. 21, 955-962 (1997).

5. A.G. DULlOO, M. FATHI, N. MENSI and L. GIRARDIER, Twenty-Four-Hour Energy Expenditure and Urinary Catecholamines of Humans Consuming Low-to-Moderate Amounts of Medium-Chain Triglycerides: A Dose-Response Study in a Human Respiratory Chamber, Eur. J. Clin. Nutr., Vol. 50, $152-$ 158 (1996).

6. L. SCALFI, A. COLTORTI and F. CONTALDO, Postprandial Thermogenesis in Lean and Obese Subjects After Meals Supplemented with Medium-Chain and Long-Chain Triglycerides, Am. J. Clin. Nutr., Vol. 53,1130-1133 (1991).

7. J.O. HILL, J.C. PETERS, D. YANG, T. SHARP, M. KALER, N.N. ABUMRAD and H.L. GREENE, Termogenesis in Human During Overfeeding With Medium-Chain Triglycerides, Metabolism, Vol. 38, 641-648 (1989).
8. The National Nutrition Survey in Japan, 2001, Ministry of Health, Labour and Welfare, Japan, Daiichisyuppan, pp. 92-97 (2001)

9. H. TSUJI, M. KASAI, H. TAKEUCHI, M. NAKAMURA, M. OKAZAKI and K. KONDO, Dietary Medium-Chain Triacylglycerols Suppress Accumulation of Body Fat in a DoubleBlind, Controlled Trial in Healthy Men and Women, J. Nutr., Vol. 131, 2853-2859 (2001).

10. N. NOSAKA, H. MAKI, Y. SUZUKI, H. HARUNA, A. OHARA, M. KASAI, H. TSUJI, T. AOYAMA, M. OKAZAKI, O. IGARASHI and K. KONDO, Effects of Margarine Containing Medium-chain Triacylglycerols on Body Fat Reduction in Humans, J. Atheroscler. Thromb., Vol. 10, 290-298 (2003).

11. J.B. WEIR, New Methods for Calculating Metabolic Rate with Special Reference to Protein Metabolism, J. Physiol., Vol. 109, 1-9 (1949).

12. J.N.S. MATTHEWS, D.G. ALTMAN, M.J. CAMPBELL and P. ROYSTON, Analysis of Serial Measurements in Medical Research, Br. Med. J., Vol. 300, 230-235 (1990).

13. R. FERRARO, S. LILLIOJA, A.M. FONTVIEILLE, R. RISING, C. BOGARDUS and E. RAVUSSIN, Lower Sedentary Metabolic Rate in Women Compared with Men, J. Clin. Invest., Vol. 90, 780-784 (1992).

14. M.M. TAI, T.P. CASTILLO and F.X. PI-SUNYER, Thermic Effect of Food During Each Phase of the Menstrual Cycle, Am. J. Clin. Nutr., Vol. 66, 1110-1115 (1997).

15. S. NEGISHI, M. ITAKURA, S. ARIMOTO, T. NAGASAWA and K. TSUCHIYA, Measurement of Foaming of Frying Oil and Effect of the Composition of TG on Foaming, J. Am. Oil Chem. Soc., Vol. 80, 471- 474 (2003). 